\title{
Prospects for Genetic Improvement in Internal Nitrogen Use Efficiency in Rice
}

\author{
Terry J. Rose ${ }^{1, *}$ (D), Tobias Kretzschmar ${ }^{2}$, Daniel L. E. Waters ${ }^{1}$, Jeanette L. Balindong ${ }^{1}$ and Matthias Wissuwa ${ }^{3}$ \\ 1 Southern Cross Plant Science, Southern Cross University, Lismore 2480, Australia; \\ daniel.waters@scu.edu.au (D.L.E.W.); j.balindong.10@student.scu.edu.au (J.L.B.) \\ 2 International Rice Research Institute (IRRI), DAPO Box 7777, Metro Manila 1301, Philippines; \\ t.kretzschmar@irri.org \\ 3 Crop, Livestock and Environment Division, Japan International Research Center for Agricultural Science, \\ Tsukuba 305-8686, Ibaraki, Japan; wissuwa@affrc.go.jp \\ * Correspondence: terry.rose@scu.edu.au; Tel.: +61-2-6620-3457
}

Received: 13 September 2017; Accepted: 26 October 2017; Published: 30 October 2017

\begin{abstract}
While improving the efficiency at which rice plants take up fertiliser nitrogen $(\mathrm{N})$ will be critical for the sustainability of rice (Oryza sativa L.) farming systems in future, improving the grain yield of rice produced per unit of $\mathrm{N}$ accumulated in aboveground plant material (agronomic $\mathrm{N}$ use efficiency; $\mathrm{NUE}_{\text {agron }}$ ) through breeding may also be a viable means of improving the sustainability of rice cropping. Given that $\mathrm{NUE}_{\text {agron }}$ (grain yield/total N uptake) is a function of harvest index (HI; grain yield/crop biomass) $\times$ crop biomass/total $\mathrm{N}$ uptake, and that improving $\mathrm{HI}$ is already the target of most breeding programs, and specific improvement in $\mathrm{NUE}_{\text {agron }}$ can only really be achieved by increasing the crop biomass/ $\mathrm{N}$ uptake. Since rice crops take up around $80 \%$ of total crop $\mathrm{N}$ prior to flowering, improving the biomass/N uptake $\left(\mathrm{NUE}_{\mathrm{veg}}\right)$ prior to, or at, flowering may be the best means to improve the $\mathrm{NUE}_{\text {agron. }}$. Ultimately, however, enhanced $\mathrm{NUE}_{\text {agron }}$ may come at the expense of grain protein unless the $\mathrm{N}$ harvest index increases concurrently. We investigated the relationships between $\mathrm{NUE}_{\text {agron, }}$ total $\mathrm{N}$ uptake, grain yield, grain $\mathrm{N}$ concentration (i.e., protein) and $\mathrm{N}$ harvest index (NHI) in 16 rice genotypes under optimal $\mathrm{N}$ conditions over two seasons to determine if scope exists to improve the NHI and/or grain protein, while maintaining or enhancing $\mathrm{NUE}_{\text {agron }}$ in rice. Using data from these experiments and from an additional experiment with cv. IR64 under optimum conditions at an experimental farm to establish a benchmark for NUE parameters in high-input, high yielding conditions, we simulated theoretical potential improvements in $\mathrm{NUE}_{\mathrm{veg}}$ that could be achieved in both low and high-input scenarios by manipulating target NHIs and grain protein levels. Simulations suggested that scope exists to increase grain protein levels in low yielding scenarios with only modest (5-10\%) reductions in current $\mathrm{NUE}_{\text {agron }}$ by increasing the current NHI from 0.6 to 0.8 . Furthermore, substantial scope exists to improve $\mathrm{NUE}_{\mathrm{veg}}$ (and therefore $\mathrm{NUE}_{\text {agron}}$ ) in high-yielding scenarios if maintaining current grain protein levels of $7.3 \%$ is not essential.
\end{abstract}

Keywords: grain protein; nitrogen harvest index; nutrient use efficiency; Oryza sativa

\section{Introduction}

Nitrogen $(\mathrm{N})$ is required in large quantities by crops and $\mathrm{N}$ deficiency frequently limits rice grain yields in traditional rice (Oryza sativa L.) farming systems [1]. Nitrogen losses from fields result in $\mathrm{N}$ fertiliser recoveries of $20-40 \%$ where $\mathrm{N}$ fertiliser is used in lowland rice production [2]. The majority of these losses are thought to be through $\mathrm{NH}_{3}$ volatilisation and full denitrification of $\mathrm{NO}_{3}{ }^{-}$to $\mathrm{N}_{2}$, as a result of the highly reduced soil conditions that occur in flooded rice systems [3]. Optimising $\mathrm{N}$ uptake and minimising potential environmental impacts by predicting the most favourable timing, rate and placement of $\mathrm{N}$ fertiliser application to lowland rice crops have thus been the subject of continued research [4-7]. 
There is significant interest in improving rice $\mathrm{N}$ efficiency through breeding in addition to optimising agronomic management of $\mathrm{N}$ fertilisers [1]. However, while yield increases through breeding and agronomy have increased grain yield per unit of applied $\mathrm{N}$, we are unaware of any examples where rice varieties have been specifically bred to have enhanced $\mathrm{N}$ efficiency. In theory, gains could be made by improving either the $\mathrm{N}$ acquisition efficiency or internal $\mathrm{N}$ utilisation efficiency $[1,8]$. Genotypic variation for $\mathrm{N}$ acquisition efficiency appears to be strongly influenced by environment with little correlation between the performance of genotypes between seasons or sites [9]; hence, selection for high $\mathrm{N}$ acquisition efficiency traits in breeding programs may be difficult to achieve.

Many definitions of internal $\mathrm{N}$ use efficiency exist in the literature, but one of the most common definitions is the grain yield produced per unit of $\mathrm{N}$ accumulated in aerial plant biomass, herein referred to as agronomic $\mathrm{N}$ use efficiency ( $\left.\mathrm{NUE}_{\text {agron }}\right)$. Variation for $\mathrm{NUE}_{\text {agron }}$ in rice is well documented $[1,8]$, but studies have been conducted almost exclusively at sub-optimal $\mathrm{N}$ supply (i.e., where grain yields are limited by insufficient $\mathrm{N}$ ), where $\mathrm{NUE}_{\text {agron }}$ was quantified as a secondary parameter in experiments primarily designed to identify genotypes with superior $\mathrm{N}$ acquisition efficiency at sub-optimal $\mathrm{N}$ supply [8]. As such, the results were likely strongly influenced by the degree of $\mathrm{N}$-deficiency stress suffered by each genotype. However, the growing use of $\mathrm{N}$ fertilisers over the past 20 years means that an increasing proportion of rice crops are grown at higher $\mathrm{N}$ supply. Despite this, we are only aware of one study that has investigated NUE parameters in rice at optimal N supply, and the data were from a multi-N rate trial at a one site in a single season [10].

In comparison, $\mathrm{NUE}_{\text {agron }}$ in wheat has been widely studied over a range of $\mathrm{N}$ rates because of the importance of grain protein in determining wheat quality. Questions have been raised as to whether pursuing $\mathrm{NUE}_{\text {agron }}$ as a breeding target in wheat is useful since it may compromise grain protein levels [11]. This is because the main components of $\mathrm{NUE}_{\text {agron }}$ (total shoot $\mathrm{N}$ uptake, grain yield, grain $\mathrm{N}$ concentration and $\mathrm{N}$ harvest index (NHI-the proportion of aboveground $\mathrm{N}$ located in the grain at maturity)) are governed by the 'law of conservation of matter' [11]. Thus, at any given level of $\mathrm{N}$ uptake and grain yield, improvements in grain protein would only be possible if the NHI increases [11]. Given that NHIs in wheat are typically $0.70-0.80$ [12], and that rapid movement of $\mathrm{N}$ from leaves to grain during grain filling limits photosynthesis, scope for further increases in NHI, and therefore $\mathrm{NUE}_{\text {agron, }}$ in wheat, seems limited if grain yields are to be maintained at the same level of plant $\mathrm{N}$ uptake. High NHIs in modern crop varieties have also been reported in other staple crops including soybeans $(0.79-0.86$; [13]) and maize $(0.74 ;$ [14]). In contrast, NHIs in rice cultivars appear to be lower, with reports of NHIs ranging from 0.44 to $0.73[9,10,15]$.

$\mathrm{NUE}_{\text {agron }}$ (grain yield/N uptake) can also be described as the product of $\mathrm{HI}$ and the inverse of aerial plant $\mathrm{N}$ concentration (total aerial biomass/aerial plant $\mathrm{N}$ uptake) as described by:

$$
\frac{\text { grain yield }}{\mathrm{N} \text { uptake }}=\frac{\text { total biomass }}{\mathrm{N} \text { uptake }} \times \frac{\text { grain yield }}{\text { total biomass }} .
$$

Improvement in $\mathrm{NUE}_{\text {agron }}$ can therefore be made by either increasing plant biomass production per unit of plant $\mathrm{N}$ accumulated, or by increasing grain yields as a proportion of total biomass (i.e., increasing HI). Given that improving $\mathrm{HI}$ is already the target of most plant breeding programs, and is not specific to $\mathrm{N}$ efficiency, specific improvements in $\mathrm{NUE}_{\text {agron }}$ can only be made by increasing the total plant biomass produced per unit of $\mathrm{N}$ uptake. Since rice plants grown under flooded conditions accumulate around $80 \%$ of total plant $\mathrm{N}$ prior to flowering $[4,16]$, improving the NUE during vegetative growth $\left(\mathrm{NUE}_{\mathrm{veg}}=\right.$ shoot biomass $/$ shoot $\mathrm{N}$ content $)$ would be the most efficient way to improve $\mathrm{NUE}_{\text {agron. }}$.

The extent to which improvement in $\mathrm{NUE}_{\mathrm{veg}}$ can be made while maintaining current grain yields and grain protein contents depends on the scope to increase NHI. However, if enhancing the protein concentration of rice grains becomes a breeding target to improve nutrition of rice consumers [17], improvement in $\mathrm{NUE}_{\text {agron }}$ (and therefore $\mathrm{NUE}_{\mathrm{veg}}$ ) may be difficult unless it is also linked to more favourable grain protein composition as opposed to total grain protein levels. Similar to other cereal 
grains, rice grains contain albumins, globulins, glutelins and prolamins [18] with the concentration of prolamins and glutelins appearing to be linked, such that reduction in one protein fraction is compensated by an increase in the other [19]. The prolamins are less digestible [20] so reducing prolamin content and increasing the content of the more easily digested glutelins would allow for simultaneous improvement in $\mathrm{NUE}_{\mathrm{veg}}$ and the nutritional quality of rice. In addition, where demand for rice is driven by grain texture, the association between high grain protein levels and lower grain quality [21] may provide an impetus to reduce grain protein levels. Under these circumstances, the scope to improve $\mathrm{NUE}_{\mathrm{veg}}$ may be significantly greater.

The present study investigated the relationships between $\mathrm{NUE}_{\text {agron }}$ (grain yield/total $\mathrm{N}$ uptake), total $\mathrm{N}$ uptake, grain yield, grain $\mathrm{N}$ concentration (i.e., protein) and $\mathrm{NHI}$ in 16 rice genotypes under optimal $\mathrm{N}$ conditions in order to determine if scope exists to improve the NHI and/or grain protein, while maintaining or enhancing $\mathrm{NUE}_{\text {agron }}$ in rice. We then investigated the accumulation and partitioning of $\mathrm{N}$ during grain filling in the elite commercial cultivar, $\mathrm{cv}$. IR64, under optimum conditions at an experimental farm to establish a benchmark for NUE parameters in high-input, high yielding conditions. Using data from these experiments, we simulate theoretical potential improvements in $\mathrm{NUE}_{\mathrm{veg}}$ that could be achieved in both typical and high-input scenarios by manipulating target NHIs and grain protein levels.

\section{Results}

\subsection{Study 1: Effect of Genotype and Season on N Efficiency Parameters in Field-Grown Rice}

\subsubsection{Mean Yield and N Efficiency Data across the Dry and Wet Seasons}

A significant effect of both season and genotype was observed for all biomass and N parameters, with the exception of non-significant season effects on straw yield and total N (Table 1). Significant season $\times$ genotype interactions were also found for all biomass and $\mathrm{N}$ parameters with the exception of HI. The average grain yield exceeded $5 \mathrm{t} \mathrm{ha}^{-1}$ in the dry season compared to $3.4 \mathrm{t} \mathrm{ha}^{-1}$ in the wet season and the higher yield during the dry season was a result of both greater total biomass yield (9235 vs. $7666 \mathrm{~kg} \mathrm{ha}^{-1}$ ) and higher HI (0.54 vs. 0.43 ) while total $\mathrm{N}$ uptake was similar across seasons (around $110 \mathrm{~kg} \mathrm{ha}^{-1}$ ) (Table 1). Consequently, grain and straw $\mathrm{N}$ concentrations were lower, and $\mathrm{NUE}_{\text {agron }}$ was higher ( 46.5 vs. $31.4 \mathrm{~kg}$ biomass $\mathrm{kg} \mathrm{N}^{-1}$ ), in the higher yielding dry season trial. Mean grain $\mathrm{N}$ concentrations were 17.4 and $13.5 \mathrm{mg} \mathrm{g}^{-1}$ for the wet season and dry season, respectively, which equates to grain protein levels of approximately $9.5 \%$ and $7.3 \%$ when expressed at $14 \%$ grain moisture. NHIs ( 0.53 in the wet season and 0.62 in the dry season) were around $20 \%$ higher than the respective HIs.

Table 1. Means of selected yield and N data parameters across 16 rice genotypes in wet season (WS) and dry season (DS) field experiments conducted between July 2012 and April 2013.

\begin{tabular}{|c|c|c|c|c|c|c|c|c|c|c|c|}
\hline & \multicolumn{4}{|c|}{ Biomass Yield } & \multicolumn{2}{|c|}{ N Concentration } & \multicolumn{3}{|c|}{ N Content } & \multicolumn{2}{|c|}{ N Efficiency } \\
\hline & GY & StY & TB & HI & GNc & StNc & GrN & StN & TotN & NUE $_{\text {agron }}$ & NHI \\
\hline \multicolumn{12}{|l|}{ Means } \\
\hline 2012 WS & 3402 & 4265 & 7666 & 0.43 & 17 & 12 & 61 & 59 & 110 & 31 & 0.53 \\
\hline 2013 DS & 5056 & 4179 & 9235 & 0.54 & 14 & 10 & 68 & 41 & 109 & 47 & 0.62 \\
\hline \multicolumn{12}{|l|}{ ANOVA } \\
\hline season & $* * *$ & $\mathrm{~ns}$ & $* * *$ & $* * *$ & $* * *$ & $* * *$ & ** & $* * *$ & ns & $* * *$ & $* * *$ \\
\hline genotype & $* * *$ & $* * *$ & $* * *$ & $* * *$ & $* * *$ & $* * *$ & $* * *$ & $* * *$ & $* * *$ & * & $* * *$ \\
\hline interaction & $* *$ & $* * *$ & $* * *$ & ns & $* * *$ & $* * *$ & $* * *$ & $* * *$ & $* * *$ & $* *$ & $* * *$ \\
\hline
\end{tabular}

${ }^{* * *}$ significant at $p<0.001,{ }^{* *}$ significant at $p<0.01,{ }^{*}$ significant at $p<0.05$, ns not significant. Abbreviations and units: grain yield (GY), straw yield (StY), total biomass yield (TB), grain $N$ content (GrN), straw N content (StN) and total biomass $\mathrm{N}$ content (TotN) are expressed in $\mathrm{kg} \mathrm{ha}^{-1}$; Grain $\mathrm{N}$ concentration (GNc) and Straw $\mathrm{N}$ concentration $(\mathrm{StNc})$ are expressed in $\mathrm{g} \mathrm{kg}^{-1}$; Agronomic $\mathrm{N}$ use efficiency $\left(\mathrm{NUE}_{\text {agron }}=\mathrm{GY} / \mathrm{Tot} \mathrm{N}\right)$ is expressed in $\mathrm{kg}$ biomass $\mathrm{kg} \mathrm{N}^{-1}$; and harvest index (HI) and $\mathrm{N}$ harvest index (NHI) are expressed as a proportion. 


\subsubsection{Genotype Variation for Yield and N Efficiency Parameters and Correlation across Seasons}

Three-fold differences in mean grain yields were observed among genotypes in the wet season, from $1854 \mathrm{~kg} \mathrm{ha}^{-1}$ (N22) to $5996 \mathrm{~kg} \mathrm{ha}^{-1}$ (BJ1), and two-fold differences were observed in the dry season, from $3384 \mathrm{~kg} \mathrm{ha}^{-1}$ (Sundensis) to $7487 \mathrm{~kg} \mathrm{ha}^{-1}$ (Kalubala Vee) (Figure 1a). Similar differences in genotype means were observed for total biomass (4356-14533 $\mathrm{kg} \mathrm{ha}^{-1}$ in the wet season and $6025-13,408 \mathrm{~kg} \mathrm{ha}^{-1}$ in the dry season; Figure $1 \mathrm{~b}$ ), and total $\mathrm{N}$ uptake $\left(64-188 \mathrm{~kg} \mathrm{~N}^{-1}\right.$ in the wet season and $80-163 \mathrm{~kg} \mathrm{~N} \mathrm{ha}^{-1}$ in the dry season; Figure 1c). Interestingly, no strong correlation between seasons was found for either grain yield $\left(R^{2}=0.06\right)$, total biomass $\left(R^{2}=0.20\right)$ or total $N$ uptake $\left(R^{2}=0.14\right)$ or genotypes, i.e., genotype rankings for these parameters were not consistent across seasons.
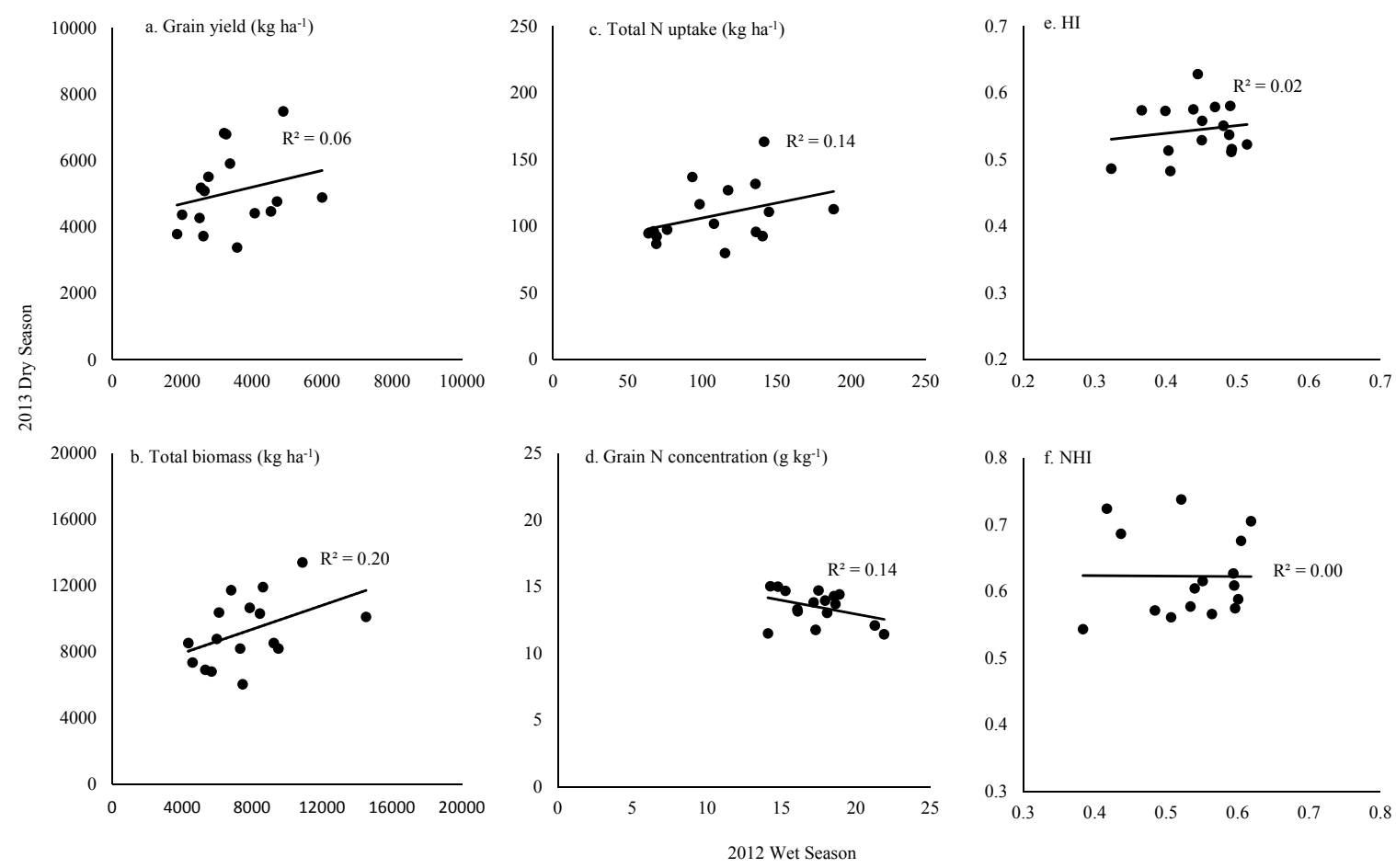

Figure 1. Correlations between key yield and nitrogen parameters Grain yield (a), total $\mathrm{N}$ uptake (b), HI (c), Total biomass (d), Grain N concentration (e) and NHI (f) across the 2012 wet season and the 2013 dry season.

Grain $\mathrm{N}$ concentrations ranged from 14.1 to $21.3 \mathrm{~g} \mathrm{~kg}^{-1}$ in the wet season and $11.4-15.0 \mathrm{~g} \mathrm{~kg}^{-1}$ in the dry season, again with no strong association between seasons $\left(R^{2}=0.14\right)$ (Figure 1d). Harvest indices ranged from 0.32 to 0.51 in the wet season and from 0.48 to 0.63 in the dry season (Figure 1e) and a similar range of variation was observed in NHIs (Figure 1f). Despite no correlation between seasons for HI or NHI, some genotypes did have consistently low or high HIs across seasons. For example, Emata-A-16-34 had the lowest $\mathrm{HI}$ in both seasons, while DJ123 had a relatively high $\mathrm{HI}$ in both seasons (0.49 in wet season and 0.58 in dry season). The low and high HIs for Emata-A-16-34 and DJ123 were mirrored in their respective NHIs.

2.1.3. Correlations between Yield and N Efficiency Parameters in the 2012 Wet Season (2012WS) and 2013 Dry Season (2013DS)

Grain yields were highly correlated to total crop biomass and to total crop N uptake in both seasons, whereas the correlation with HI was consistently weak (Table 2). Interestingly, there was no significant correlation between grain yield and grain $\mathrm{N}$ concentration in either season. Crop NHI was significantly and positively correlated to $\mathrm{HI}$ in the dry season $(r=0.68)$ and wet season $(r=0.74)$, 
but was not significantly correlated to total crop $\mathrm{N}$ uptake in either season (Table 2). Interestingly, $\mathrm{NUE}_{\text {agron }}$ had also no significant correlation with crop $\mathrm{N}$ uptake in either season, but was significantly yet weakly correlated with grain yield.

Table 2. Correlations between key biomass and N parameters in wet season (WS) and dry season (DS) field experiments.

\begin{tabular}{ccccccccccccc}
\hline \multirow{2}{*}{ 2013DS } & \multicolumn{4}{c}{ Biomass Yield } & \multicolumn{3}{c}{ N Concentration } & \multicolumn{3}{c}{ N Content } & \multicolumn{2}{c}{ N Efficiency } \\
\cline { 2 - 12 } & GY & StY & TotY & HI & GNc & StNc & GrN & StN & TotN & NUE agron & NHI \\
\hline GY & & 0.78 & 0.93 & 0.37 & -0.07 & -0.26 & 0.93 & 0.46 & 0.82 & 0.30 & 0.42 \\
StY & 0.73 & & 0.95 & -0.27 & 0.21 & -0.09 & 0.83 & 0.77 & 0.92 & -0.19 & -0.03 \\
TotY & 0.95 & 0.91 & & 0.02 & 0.09 & -0.18 & 0.93 & 0.67 & 0.92 & 0.04 & 0.18 \\
HI & 0.48 & -0.23 & 0.19 & & -0.39 & -0.29 & 0.22 & -0.44 & -0.09 & 0.8 & 0.74 \\
GNc & -0.15 & -0.27 & -0.22 & 0.13 & & 0.27 & 0.27 & 0.33 & 0.34 & -0.67 & -0.03 \\
StNc & -0.14 & -0.23 & -0.19 & 0.09 & 0.04 & & -0.19 & 0.52 & 0.15 & -0.69 & -0.73 \\
GrN & 0.92 & 0.62 & 0.85 & 0.51 & 0.23 & -0.15 & & 0.53 & 0.90 & 0.08 & 0.41 \\
StN & 0.54 & 0.70 & 0.65 & -0.13 & -0.24 & 0.51 & 0.42 & & 0.85 & -0.57 & -0.50 \\
TotN & 0.91 & 0.76 & 0.91 & 0.32 & 0.06 & 0.12 & 0.92 & 0.75 & & -0.25 & 0 \\
NUE & 0.47 & 0.16 & 0.36 & 0.49 & -0.52 & -0.59 & 0.28 & -0.27 & 0.08 & & 0.74 \\
NHI & 0.38 & -0.08 & 0.20 & 0.68 & 0.39 & -0.59 & 0.54 & -0.51 & 0.17 & 0.58 & \\
\hline
\end{tabular}

Statistical significance of correlations: $p<0.05=0.29, p<0.01=0.37$. Abbreviations and units: grain yield (GY), straw yield (StY), total biomass yield (TotY), grain $\mathrm{N}$ content $(\mathrm{GrN})$, straw $\mathrm{N}$ content $(\mathrm{StN})$ and total biomass $\mathrm{N}$ content (TotN) are expressed in $\mathrm{kg} \mathrm{ha}^{-1}$; grain $\mathrm{N}$ concentration (GNc) and straw $\mathrm{N}$ concentration (StNc) are expressed in $\mathrm{g} \mathrm{kg}^{-1}$; agronomic $\mathrm{N}$ use efficiency $\left(\mathrm{NUE}_{\text {agron }}=\mathrm{GY} / \mathrm{TotN}\right)$ is expressed in $\mathrm{kg}$ biomass $\mathrm{kg} \mathrm{N}^{-1}$; and harvest index (HI) and $\mathrm{N}$ harvest index (NHI) are expressed as a proportion.

2.2. Study 2: Accumulation and Partitioning of $N$ during Grain Filling in the High Yielding Rice Mega-Variety IR64 under Optimum Conditions during the Dry Season at the International Rice Research Institute (IRRI)

The crop accumulated $16.8 \mathrm{tha}^{-1}$ aboveground biomass and around $175 \mathrm{~kg} \mathrm{~N} \mathrm{ha}^{-1}$ by maturity (Figure 2a), with a grain yield of $10.4 \mathrm{t} \mathrm{ha}^{-1}$ at $11.7 \mathrm{~g} \mathrm{~N} \mathrm{~kg}^{-1}$ grain (Supplementary Table S1). The accumulation of $\mathrm{N}$ in the grain during the 28-day grain filling period followed a similar pattern to grain biomass accumulation with almost parallel increases for both in the period from five days after anthesis (DAA) until maturity (Figure 2b). In contrast, plants accumulated only around $20 \%$ of their final $\mathrm{N}$ content during the grain filling period, but accumulated around $50 \%$ of their final biomass during this period (Figure 2a), resulting in an overall decline in the concentration of $\mathrm{N}$ in total aboveground biomass and in vegetative aboveground biomass during the latter stages of grain filling (Supplementary Table S1). Whole aboveground plant $\mathrm{N}$ concentration declined from $17.2 \mathrm{~g} \mathrm{~N} \mathrm{~kg}^{-1}$ biomass at anthesis to $10.4 \mathrm{~g} \mathrm{~N} \mathrm{~kg}^{-1}$ biomass at maturity, while straw $\mathrm{N}$ concentration at maturity was only $8.4 \mathrm{~g} \mathrm{~N} \mathrm{~kg}^{-1}$ biomass. At maturity, the harvest index was 0.6 while the NHI was 0.69 . 
a) Aerial tissue

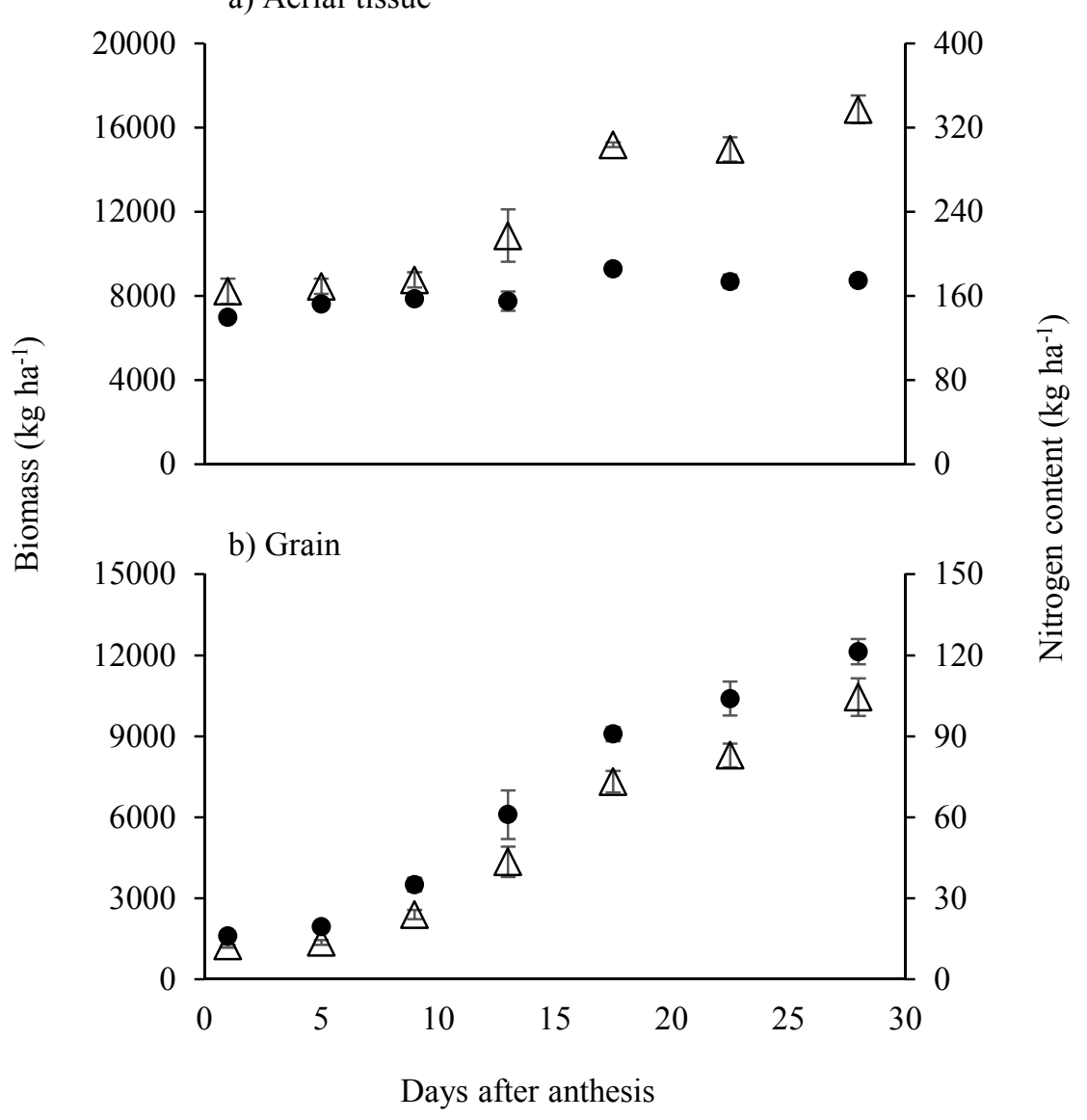

Figure 2. Accumulation of biomass (open triangles) and nitrogen (closed circles) in (a) aerial tissue and (b) grain of rice cv. IR64 grown under optimum conditions. Error bars represent SEM $(n=3)$.

\subsection{Study 3: Simulated Impact of Changes in Grain Protein and NHI on NUEveg}

Using mean varietal data from the farmer field site in Pangil ( $5 \mathrm{tha}^{-1}$ crop) and IRRI (10.4 $\mathrm{t} \mathrm{ha}^{-1}$ crop), we first investigated changes in $\mathrm{NUE}_{\mathrm{veg}}$ at flowering with changes to grain protein levels and $\mathrm{NHI}$.

\subsubsection{Low Yielding Germplasm/Environments}

If grain protein levels were maintained at the current $8.1 \%$ but NHI increased from 0.60 to 0.80 , an increase in $\mathrm{NUE}_{\mathrm{veg}}$ of over $25 \%$ (from 57.8 to 77.2 biomass $\mathrm{g} \mathrm{N}^{-1}$ ) is possible because the crop $\mathrm{N}$ uptake required to maintain a $5 \mathrm{t} \mathrm{ha}^{-1}$ yield at $8.1 \%$ protein is reduced by $27 \mathrm{~kg} \mathrm{~N} \mathrm{ha}^{-1}$ or $25 \%$ (Simulation 1, Table 3). Alternatively, if the NHI increased from 0.60 to 0.80 , it would be possible to achieve grain protein levels of $12 \%$ with only a small additional crop $\mathrm{N}$ uptake requirement (120 instead of $108 \mathrm{~kg} \mathrm{~N} \mathrm{ha}^{-1}$ ). This would increase shoot $\mathrm{N}$ concentrations at flowering from 17.3 to $19.2 \mathrm{mg} \mathrm{g}^{-1}$

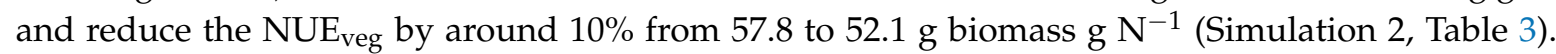
However, if grain protein levels were to be increased from $8.1 \%$ to $12 \%$ through breeding without any change to the NHI, shoot $\mathrm{N}$ concentration at anthesis would need to increase from $17.3 \mathrm{mg} \mathrm{g}^{-1}$

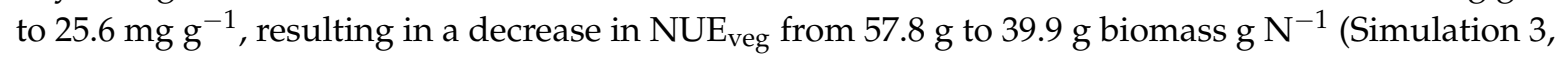
Table 3). 
Table 3. Simulating possible changes in nitrogen uptake and $\mathrm{NUE}_{\mathrm{veg}}$ in dependence on target levels of grain protein concentrations or NHI. At constant target protein levels breeding for increased NHI would lower the minimum plant $\mathrm{N}$ content required to fill grains and that could improve the $\mathrm{NUE}_{\mathrm{veg}}$ at flowering.

\begin{tabular}{|c|c|c|c|c|c|c|}
\hline $\begin{array}{l}\text { Grain Yield } \\
\left(\mathrm{kg} \mathrm{ha}^{-1}\right)\end{array}$ & $\begin{array}{c}\text { Grain } \\
\text { Protein (\%) }\end{array}$ & $\begin{array}{c}\text { Grain } \mathrm{N} \\
\left(\mathrm{kg} \mathrm{N} \mathrm{ha}^{-1}\right)\end{array}$ & NHI & $\begin{array}{c}\text { Total N Uptake } \\
\left(\text { (kg N ha }^{-1}\right)\end{array}$ & $\begin{array}{l}\text { Shoot N Concentration } \\
\text { at Flowering }\left(\mathrm{mg} \mathrm{g}^{-1}\right)\end{array}$ & $\begin{array}{l}\text { NUE }_{\text {veg }} \text { at Flowering } \\
\left(\mathrm{g} \text { Biomass } \mathrm{g} \mathrm{N}^{-1}\right)\end{array}$ \\
\hline \multicolumn{7}{|c|}{$5 \mathrm{tha}^{-1}$ grain yield } \\
\hline Simulation 1 & 8.1 & 65 & 0.80 & 81 & 13.0 & 77.2 \\
\hline Simulation 2 & 12 & 96 & 0.80 & 120 & 19.2 & 52.1 \\
\hline Simulation 3 & 12 & 96 & 0.60 & 160 & 25.6 & 39.1 \\
\hline \multicolumn{7}{|c|}{$10.4 \mathrm{t} \mathrm{ha}^{-1}$ grain yield } \\
\hline IRRI data & 7.3 & 121 & 0.69 & 176 & 16.9 & 59.1 \\
\hline Simulation 5 & 7.3 & 121 & 0.8 & 151 & 14.6 & 68.5 \\
\hline Simulation 6 & 12 & 201 & 0.80 & 250 & 24.0 & 41.7 \\
\hline Simulation 7 & 12 & 201 & 0.69 & 291 & 27.8 & 39.9 \\
\hline
\end{tabular}

Note: International Rice Research Institute (IRRI) data assumes $10.4 \mathrm{t}$ yield and $\mathrm{HI}$ of 0.60, Pangil data assumes $5 \mathrm{t}$ yield and $\mathrm{HI}$ of 0.50 . The simulation presumes that $\mathrm{HI}$ and $\mathrm{NHI}$ are not directly affected by grain yield or total $\mathrm{N}$ uptake. It is assumed that $20 \%$ of the plant $\mathrm{N}$ accumulation occurs after anthesis.

If we simulate lower grain protein levels (5\%) without any alteration to the NHI of 0.60 , shoot $\mathrm{N}$ concentrations at anthesis of only $10.7 \mathrm{mg} \mathrm{g}^{-1}$ would be required, i.e., an $\mathrm{NUE}_{\mathrm{veg}}$ of $93.5 \mathrm{~g}$ biomass $\mathrm{g} \mathrm{N}^{-1}$ could be achieved (Simulation 4, Table 3 ). As a consequence, the crop would only be required to take up around $67 \mathrm{~kg} \mathrm{~N} \mathrm{ha}^{-1}$, around two thirds of the uptake required $\left(108 \mathrm{~kg} \mathrm{~N} \mathrm{ha}^{-1}\right)$ at current grain protein levels of $8.1 \%$.

\subsubsection{High Yielding Germplasm/Environments}

If grain protein levels were maintained at $7.3 \%$ but the harvest index was increased to 0.80 , an increase in $\mathrm{NUE}_{\mathrm{veg}}$ of roughly $15 \%$ would be attainable (Simulation 5), which is not as dramatic as that observed in the lower yielding scenario because the NHI in the high yielding scenario is already 0.69. While an increase in grain protein without concomitant changes in NHI would have a similar effect on $\mathrm{NUE}_{\mathrm{veg}}$ to that observed in the low yielding scenario, a $30 \%$ reduction in $\mathrm{NUE}_{\mathrm{veg}}$ would still occur (from to $59.1 \mathrm{~g}$ biomass $\mathrm{g} \mathrm{N}^{-1}$ to $41.7 \mathrm{~g}$ biomass $\mathrm{g} \mathrm{N}^{-1}$ ) if $12 \%$ protein was obtained and the NHI increased to 0.80, again as a result of the existing NHI of 0.69 (Simulations 6 and 7). Where the NHI is already relatively high (around 0.7), it seems that any large improvements in $\mathrm{NUE}_{\mathrm{veg}}$ would only be possible if the grain protein was reduced. If grain protein levels were lowered to $5 \%$ without any alteration of the NHI of 0.69 , shoot $\mathrm{N}$ concentrations at an anthesis of only $11.6 \mathrm{mg} \mathrm{g}^{-1}$ would be required, i.e., an $\mathrm{NUE}_{\mathrm{veg}}$ of $86.3 \mathrm{~g}$ biomass $\mathrm{g} \mathrm{N}^{-1}$ (Simulation 8). As occurred in the low yielding scenario, this would consequently reduce the crop $\mathrm{N}$ uptake requirement by around a third (from $176 \mathrm{~kg} \mathrm{~N}^{-1}$ to $121 \mathrm{~kg} \mathrm{~N} \mathrm{ha}^{-1}$ ).

\section{Discussion}

To improve $\mathrm{N}$ use efficiency of rice systems, more grain needs to be produced per unit of $\mathrm{N}$ fertiliser applied. From a breeding perspective, this could be achieved by developing rice cultivars that can acquire a larger proportion $\mathrm{N}$ fertiliser applied to the crop, or by developing rice cultivars that can maintain current grain yields with lower plant $\mathrm{N}$ content. Previous studies have indicated that $\mathrm{N}$ acquisition is predominantly driven by environment rather than genetics, suggesting that breeding cultivars with consistently higher $\mathrm{N}$ uptake across environments may be difficult to achieve [9]. We therefore focussed on whether scope exists to maintain grain yields of rice with lower plant $\mathrm{N}$ content, bearing in mind that grain protein levels have critical implications for grain quality and human nutrition. 
The mean grain yields of the modern varieties (IR64, IR8 and IR36) in the wet and dry seasons at Pangil were around the expected average yield of $6 \mathrm{t} \mathrm{ha}^{-1}$ for irrigated fields in the Philippines [22]. The lower yields in the wet season reflected the lower total biomass yields as well as lower HIs that are typically observed under wet season conditions because of higher pre-anthesis temperatures and lower solar radiation [23]. The variation in all yield and $\mathrm{N}$ parameters measured in both seasons (Figure 1) is consistent with the wide variation for these parameters reported in a single site, single season study by Singh et al. [9]. However, as has been reported in studies under low $\mathrm{N}$ conditions [9], we found little correlation between seasons for these parameters, and significant season $\times$ genotype effects were observed for all parameters except HI (Table 1 ).

Strong genotype, season, and season $\times$ genotype interactions were observed for grain protein content. Based on similar observations, Ladha et al. [8] concluded that it would be difficult to select for grain protein because grain $\mathrm{N}$ concentration is influenced more by environment than genotype. However, grain protein in wheat is also strongly influenced by environment [11], yet it has been successfully manipulated through breeding to improve grain protein concentrations to meet market demands. Thus, it seems likely that grain protein concentrations in rice could be manipulated if it was prioritised in breeding programs.

In Experiment 1 (typical farmer field conditions), all varieties received the recommended application of $\mathrm{N}$ fertiliser (150 $\mathrm{kg} \mathrm{N} \mathrm{ha}^{-1}$ in the wet season and $180 \mathrm{~kg} \mathrm{~N} \mathrm{ha}^{-1}$ in the dry season), which resulted in grain $\mathrm{N}$ concentrations ranging from 14 to $21 \mathrm{~g} \mathrm{~kg}^{-1}$ in the wet season to $11-15 \mathrm{~g} \mathrm{~kg}^{-1}$ in the dry season. These concentrations are substantially lower than the grain $\mathrm{N}$ concentrations of 18-28 $\mathrm{g} \mathrm{kg}^{-1}$ observed across a range of wheat genotypes supplied with optimum $\mathrm{N}$ fertiliser [11]. The relatively low grain $\mathrm{N}$ concentrations, coupled with relatively low NHIs (mean across varieties was 0.53 in the wet season and 0.62 in the dry season), suggest that there may be scope to improve the $\mathrm{NUE}_{\text {agron }}$ through improvements in $\mathrm{NUE}_{\mathrm{veg}}$ in lower yielding genotypes/environments while maintaining the same grain yield and protein levels if NHI could be altered through breeding.

Our simulation suggests that, even if grain protein was maintained at around $8 \%$, increases in $\mathrm{NUE}_{\mathrm{veg}}$ of over $25 \%$ could theoretically be achieved by increasing the NHI from 0.6 to 0.8 (Simulation 1 , Table 3). However, in many low-yielding environments in developing countries, increasing grain protein level and composition through breeding has been suggested as a means to increase the protein intake of the population, since cereals often form a large proportion of the diet [17]. With this simulation, it was demonstrated that grain protein levels could be theoretically increased to $12 \%$ with as little as a $10 \%$ reduction in current $\mathrm{NUE}_{\text {agron }}$ if the NHI can be increased from 0.6 to 0.8 .

A typical yield for farmers' fields in high-input temperate rice systems is $10 \mathrm{tha}^{-1}$ [5], which is similar to the yield of the mega-variety IR64 in our small plots on the IRRI experimental farm but high compared to the average $6 \mathrm{t} \mathrm{ha}^{-1}$ yields for irrigated fields in the Philippines [22]. The relatively high yield of IR64 was likely not only a result of the weed free, high nutrient conditions, but because management of the trial enabled many later flowering tillers to produce grain that contributed to final yields. While this may not be typical of management in farmers' fields, it provided benchmark NUE parameters for high-input crops to enable simulations of possible improvements in $\mathrm{NUE}_{\mathrm{veg}}$ that could be achieved in high input, high yielding scenarios.

Interestingly, even with a $\mathrm{HI}$ of 0.6 the NHI of cv. IR64 under optimum conditions was only 0.69 , which is still lower than NHIs of other crops including wheat $(0.70-0.80$; [12]), maize $(0.74 ;$ [14]) and soybean $(0.79-0.86$; [13]) where the HIs were closer to 0.5 . However, even if the NHI in high-yielding scenarios could be increased to 0.8 , only modest improvements in $\mathrm{NUE}_{\mathrm{veg}}$ of around $15 \%$ could be attained if current yield and protein levels were maintained (Table 3).

The greatest scope to improve the $\mathrm{NUE}_{\mathrm{veg}}$, and therefore the $\mathrm{NUE}_{\mathrm{agron}}$, in these high yielding scenarios arises through reductions in grain protein levels. Rice prolamins are poorly digested by humans $[20,24]$ so it is possible that the nutritional value of the rice could be maintained if grain total protein was reduced through large reductions in prolamin content in combination with a smaller 
increase in glutelin content. Assuming grain protein levels could be reduced to $5 \%$, increases in $\mathrm{NUEv}_{\text {eg }}$ of over $30 \%$ could be attained without any change to the current NHI of 0.69 .

\section{Materials and Methods}

\subsection{Study 1: Effect of Genotype and Season on N Efficiency Parameters in Field-Grown Rice}

Field trials were established in a farmer's field at Pangil, Laguna, Philippines, in the 2012 wet season (herein referred to as 'wet season') and the 2013 dry season (herein referred to as 'dry season') in soil of $\mathrm{pH} 4.7$ (1:1 soil-water) and Bray P of 4.1. All trials were composed of 5-row plots with dimensions $1.0 \times 3.0 \mathrm{~m}$ arranged in a randomised complete block design with three replicates. Seedlings were raised in a glasshouse at the International Rice Research Institute (IRRI), Los Baños, Philippines.

Seeds of all genotypes were sown into trays containing commercial nursery seedling mix in a glasshouse at IRRI. Seedlings were transplanted by hand into the field in rows $0.2 \mathrm{~m}$ apart with a hill spacing of $0.2 \mathrm{~m}$ within rows (i.e., 25 hills $\mathrm{m}^{-2}$ ), with one plant per hill. Fields were kept flooded as per typical farmer management. Weeds were controlled by hand and pests (snails and rats) were controlled with chemical treatments when necessary.

In the 2012WS, seedlings were transplanted at 16 days after sowing (DAS) (on 6 July 2012) and basal fertilisers were applied 12 days after transplanting (DAT) on 18 July by broadcasting N, P, K and Zn onto plots at the following rates: $\left(\mathrm{kg} \mathrm{ha}^{-1}\right): 90 \mathrm{~N}, 30 \mathrm{P}, 30 \mathrm{~K}$ and $2 \mathrm{Zn}$. A further $30 \mathrm{~kg} \mathrm{~N} \mathrm{ha}^{-1}$ was applied (broadcast as urea) at active tillering (36 DAT) and panicle initiation (56 DAT).

In the 2013DS, seeds were transplanted by hand into the field at 19 DAS (on 9 January 2013) and basal fertilisers were applied at five DAT on 14 January by broadcasting N, P, K and Zn onto plots at the following rates: $\left(\mathrm{kg} \mathrm{ha}^{-1}\right): 120 \mathrm{~N}, 60 \mathrm{P}, 60 \mathrm{~K}$ and $2 \mathrm{Zn}$. Higher basal fertiliser rates were used because of the higher yield potential in the dry season. A further $30 \mathrm{~kg} \mathrm{~N} \mathrm{ha}^{-1}$ was applied (broadcast as urea) at active tillering (36 DAT) and panicle initiation (56 DAT). Crop management occurred as per the wet season trial.

\subsubsection{Plant Material}

Sixteen rice genotypes, including three modern varieties (IR8, IR36, IR64), and 13 traditional cultivars from various regions across Asia belonging to the indica and aus gene pools of rice (indica: Emata-A-16-34, Dawebyan, Mudgo, RTS14, Sadri Tor Misri, Sundensis, Yodanya; aus: BJ1, DJ123, Kalubala Vee, N22, Santhi Sufaid, Surjamkuhi), were obtained from the IRRI gene bank and were cultivated in both trials. Such broad genetic diversity enabled us to look beyond the rather narrow gene pool included in many agronomical studies and to see if a higher degree of variation for NUE-related traits can be found in a more diverse set of rice accessions.

\subsubsection{Measurements}

Maturity varied among genotypes from 90 to 110 days after transplanting, with Yodanya flowering the earliest and IR64 flowering last of the cultivars. At maturity, eight plants from the middle two rows were harvested by severing shoots $10 \mathrm{~mm}$ above the soil surface. Grain was manually threshed from the straw, and all plant material was then dried in an oven at $60^{\circ} \mathrm{C}$ for 5 days. Total $\mathrm{N}$ in finely ground $0.2 \mathrm{~g}$ subsamples of biomass was measured by Dumas combustion using a LECO TruMAC CNS analyser (LECO Corporation, Saint Joseph, MI, USA) with the combustion chamber set at $900{ }^{\circ} \mathrm{C}$. All plant biomass and $\mathrm{N}$ content data are presented per ha based on plant spacing given above. 
4.2. Study 2: Accumulation and Partitioning of $N$ during Grain Filling in the High Yielding Rice Mega-Variety IR64 under Optimum Conditions

\subsubsection{Field Site}

The experiment was undertaken at IRRI during the dry season from January to April 2013, within the framework of a larger plant nutrition trial laid out in a randomised block design. Three replicate plots $(5 \mathrm{~m} \times 10 \mathrm{~m})$ that had received optimum amounts of $\mathrm{N}$, phosphorus $(\mathrm{P})$ and potassium $(\mathrm{K})$ fertilisers were selected and used to quantify the accumulation and partitioning of $\mathrm{N}$ during grain filling. The soil had a pH (1:1 soil-water) 7.3, \% C 2.33, \% N 0.192, Bray P $8.5 \mathrm{mg} \mathrm{kg}^{-1}$, exchangeable K (meq $100 \mathrm{~g}^{-1}$ ) 0.54 and available $\mathrm{Zn} 0.9 \mathrm{mg} \mathrm{kg}^{-1}$. On 4 January 2013, three days prior to transplanting, basal fertiliser was broadcast onto the plots at the following rates $\left(\mathrm{kg} \mathrm{ha}^{-1}\right): 90 \mathrm{~N}, 26 \mathrm{P}, 33 \mathrm{~K}$ and $2 \mathrm{Zn}$.

\subsubsection{Cultivation of Rice Plants}

Rice (cv. IR64) seeds were sown into trays containing commercial nursery seedling mix in a glasshouse at IRRI. Seedlings were transplanted by hand into the field at 21 DAS in rows $0.2 \mathrm{~m}$ apart with a hill spacing of $0.2 \mathrm{~m}$ within rows (i.e., 25 hills $\mathrm{m}^{-2}$ ), with one plant per hill. A further $90 \mathrm{~kg} \mathrm{ha}^{-1}$ $\mathrm{N}$ (as urea) was broadcast in three splits of $30 \mathrm{~kg} \mathrm{ha}^{-1} \mathrm{~N}$ at 20, 40 and 60 days after transplanting. Plants were cultivated under typical fully flooded practice, with weeds controlled by hand and snails controlled by chemical application when required. To achieve maximum potential yields for the simulation study, irrigation during grain filling was managed to enable as many later flowering tillers as possible to reach physiological maturity.

\subsubsection{Measurements}

Anthesis occurred on the 18 March and plants reached physiological maturity at 28 DAA. Three plants per plot were randomly harvested and pooled at $0,5,8-10,12-14,17-19,22-23$ and 28 DAA by cutting shoots about $10 \mathrm{~mm}$ above the soil surface. The range of days (e.g., 8-10 DAA) reflects the range of maturity dates among plants within the same plot (differing by up to $2 \mathrm{~d}$ ). For simplicity, harvest time-points are referred to as $0,5,9,13,18,23$ and 28 DAA.

Plant material was oven-dried at $60{ }^{\circ} \mathrm{C}$ for 5 days and then separated into grain (husk plus caryopsis), stem (stem plus leaf sheath), flag leaf (blade), second and third leaves (blade), older leaves (blade) and late tillers. Any grain from tillers that were near physiological maturity but still high in moisture content were dried and recorded in the grain yield. Late tillers therefore only comprised those that had not yet flowered or those that contained grains at or before the milky dough stage. Total $\mathrm{N}$ was quantified as per experiment 1 , and total $\mathrm{N}$ in aboveground tissues was calculated by summing the $\mathrm{N}$ content of individual organs. All plant biomass and $\mathrm{N}$ content data are presented on a per ha basis.

\subsection{Study 3: Simulated Impact of Changes in Grain Protein and NHI on NUEveg}

We simulated potential improvements in $\mathrm{NUE}_{\mathrm{veg}}$ at flowering that could be achieved while adhering to the 'law of conservation of matter' by modifying (through breeding) the NHI under a range of desired grain protein levels. Mean yield and $\mathrm{N}$ efficiency parameter data from the Pangil trials and data from the IRRI trial were to simulate possible changes in $\mathrm{NUE}_{\mathrm{veg}}$ in low input $\left(5 \mathrm{t} \mathrm{ha}^{-1}\right.$ yield target, $\mathrm{HI}$ of 0.50$)$ and high input (10.4 $\mathrm{t} \mathrm{ha}^{-1}$ yield target, $\mathrm{HI}$ of 0.60$)$ scenarios, respectively. The model investigating potential changes in $\mathrm{NUE}_{\mathrm{veg}}$ at flowering as a result of changes in grain protein or $\mathrm{NHI}$ used the following four equations:

$$
\begin{gathered}
\mathrm{HI}=\frac{\text { Grain yield at maturity }}{\text { Total biomass yield at maturity }}, \\
\mathrm{NHI}=\mathrm{HI} \times \frac{\text { Grain N concentration at maturity }}{\text { Total biomass N concentration at maturity }},
\end{gathered}
$$


Total $\mathrm{N}$ uptake $=$ Total biomass $\mathrm{N}$ concentration $\times$ Total biomass yield,

$$
\mathrm{NUE}_{\mathrm{veg}}=\frac{\text { Total biomass at maturity } \times 0.5}{\text { Total } \mathrm{N} \text { uptake at maturity } \times 0.8} .
$$

The model assumes that $20 \%$ of the total crop $\mathrm{N}$ uptake occurs during grain filling (see denominator in Equation (5)), and that the NHI can vary independently from grain yield or total $\mathrm{N}$ uptake.

\section{Conclusions}

Scope exists to increase grain protein levels in low yielding scenarios with only modest (5-10\%) reductions in current $\mathrm{NUE}_{\text {agron }}$ by increasing the NHI from 0.6 to 0.8 and substantial scope exists to improve $\mathrm{NUE}_{\mathrm{veg}}$ (and therefore $\mathrm{NUE}_{\mathrm{agron}}$ ) in high-yielding scenarios if maintaining current grain protein levels is not essential. We suggest attempts to improve $\mathrm{NUE}_{\text {agron }}$ in rice by exploiting genetic variation should focus on identifying variation for biomass production per unit of plant $\mathrm{N}$ uptake during vegetative growth stages $\left(\mathrm{NUE}_{\mathrm{veg}}\right.$ ) because this ultimately contributes to $\mathrm{NUE}_{\text {agron }}$ (grain yield per unit of $\mathrm{N}$ uptake) and is independent of the HI. We previously developed methods to screen for phosphorus use efficiency at the vegetative stage [25,26], and these methods enabled the successful mapping of loci associated with enhanced phosphorus use efficiency at the vegetative stage [27]. We propose that similar screening techniques could be developed to enable mapping of loci associated with enhanced $\mathrm{NUE}_{\mathrm{veg}}$ in rice. From an environmental perspective, improving the overall efficiency of $\mathrm{N}$ efficiency in rice production systems needs to combine genetic enhancements in $\mathrm{NUE}_{\text {agron }}$ with greater crop capture of applied $\mathrm{N}$ fertiliser, since recoveries of $\mathrm{N}$ fertiliser in flooded systems remain low.

Supplementary Materials: The following are available online at http://www.mdpi.com/2073-4395/7/4/70/s1, Table S1: Nitrogen concentrations in rice (cv. IR64) grain and aboveground biomass during grain filling under high yielding field conditions.

Acknowledgments: This work was funded through internal research support from Southern Cross University, Japan international Research Center for Agricultural Science and The International Rice Research Institute.

Author Contributions: T.R., M.W. and T.K. conceived and designed the experiments, T.R. and M.W. analyzed the data, T.R., M.W., J.B., D.W. and T.K. wrote the paper.

Conflicts of Interest: The authors declare no conflict of interest.

\section{References}

1. Vinod, K.K.; Heuer, S. Approaches towards nitrogen- and phosphorus-efficient rice. AoB Plants 2012. [CrossRef] [PubMed]

2. Cassman, K.G.; Gines, G.C.; Dizon, M.A.; Samson, M.I.; Alcantara, J.M. Nitrogen-use efficiency in tropical lowland rice systems: Contributions from indigenous and applied nitrogen. Field Crops Res. 1996, 47, 1-12. [CrossRef]

3. Linquist, B.A.; Liu, L.; van Kessel, C.; van Groenigen, K.J. Enhanced efficiency nitrogen fertilizers for rice systems: Meta-analysis of yield and nitrogen uptake. Field Crops Res. 2013, 154, 246-254. [CrossRef]

4. Cassman, K.G.; Peng, S.; Olk, D.C.; Ladha, J.K.; Reichardt, W.; Dobermann, A.; Singh, U. Opportunities for increased nitrogen-use efficiency from improved resource management in irrigated rice systems. Field Crops Res. 1998, 56, 7-39. [CrossRef]

5. Dunn, B.W.; Dunn, T.S.; Beecher, H.G. Nitrogen timing and rate effects on growth and grain yield of delayed permanent water rice in south-east Australia. Crop Pasture Sci. 2014, 65, 878-887. [CrossRef]

6. Dunn, B.W.; Dunn, T.S.; Orchard, B.A. Nitrogen rate and timing effects on growth and yield of drill-sown rice. Crop Pasture Sci. 2016, 67, 1149-1157. [CrossRef]

7. Russell, C.A.; Dunn, B.W.; Batten, G.D.; Williams, R.L.; Angus, J.F. Soil tests to predict optimum fertilizer nitrogen rate for rice. Field Crops Res. 2006, 97, 286-301. [CrossRef]

8. Ladha, J.K.; Kirk, G.J.D.; Bennet, J.; Peng, S.; Reddy, C.K.; Singh, U. Opportunities for increased nitrogen-use efficiency from improved lowland rice germplasm. Field Crops Res. 1998, 56, 41-71. [CrossRef] 
9. Tirol-Padre, A.; Ladha, J.K.; Singh, U.; Laureles, E.; Punzalan, G.; Akita, S. Grain yield performance of rice genotypes at suboptimal levels of soil $\mathrm{N}$ as affected by $\mathrm{N}$ uptake and utilization efficiency. Field Crops Res. 1996, 46, 127-143. [CrossRef]

10. Singh, U.; Ladha, J.K.; Castilloa, E.G.; Punzalan, G.; Tirol-Padre, A.; Duqueza, M. Genotypic variation in nitrogen use efficiency in medium- and long-duration rice. Field Crop Res. 1998, 58, 35-53. [CrossRef]

11. Barraclough, P.B.; Howarth, J.R.; Jones, J.; Lopez-Bellido, R.; Parmar, S.; Shepherd, C.E.; Hawkesford, M.J. Nitrogen efficiency of wheat: Genotypic and environmental variation and prospects for improvement. Eur. J. Agron. 2010, 33, 1-11. [CrossRef]

12. Brancourt-Humel, M.; Doussinault, G.; Lecomte, C.; Bernard, P.; Le Buance, B.; Trottet, M. Genetic improvement of agronomic traits of winter wheat cultivars released in France from 1946-1992. Crop Sci. 2003, 43, 37-45. [CrossRef]

13. Crafts-Brandner, S.J. Phosphorus nutrition influence on leaf senescence in soybean. Plant Physiol. 1992, 92, 1128-1132. [CrossRef]

14. Teyker, R.H.; Moll, N.A.; Jackson, N.A. Divergent selection among maize seedlings for nitrate uptake. Crop Sci. 1989, 29, 879-884. [CrossRef]

15. Fageria, N.K.; Barbosa Filho, M.P. Nitrogen use efficiency in lowland rice genotypes. Commun. Soil Sci. Plant Anal. 2001, 32, 2079-2089. [CrossRef]

16. Rose, T.J.; Mori, A.; Julia, C.; Wissuwa, M. Screening for internal phosphorus utilisation efficiency: Comparison of genotypes at equal shoot content is critical. Plant Soil 2016, 401, 77-91. [CrossRef]

17. Wong, H.W.; Liu, Q.; Sun, S.S.M. Biofortification of rice with lysine using endogenous histones. Plant Mol. Biol. 2015, 87, 235-248. [CrossRef] [PubMed]

18. Shewry, P.R.; Halford, N.G. Cereal seed storage proteins: Structures, properties and role in grain utilization. J. Exp. Bot. 2002, 53, 947-958. [CrossRef] [PubMed]

19. Iida, S.; Amano, E.; Nishio, T. A rice (Oryza sativa L.) mutant having a low content of glutelin and a high content of prolamine. Theor. Appl. Genet. 1993, 87, 374-378. [CrossRef] [PubMed]

20. Ogawa, M.; Kumamaru, T.; Satoh, H.; Iwata, N.; Omura, T.; Kasai, Z.; Tanaka, K. Purification of protein body-1 of rice seed and its polypeptide composition. Plant Cell Physiol. 1987, 28, 1517-1528.

21. Martin, M.; Fitzgerald, M.A. Proteins in Rice Grains Influence Cooking Properties. J. Cereal Sci. 2002, 36, 285-294. [CrossRef]

22. Brennan, J.P.; Malabayabas, A. Impacts of IRRI Germplasm on the Philippines since 1985. International Rice Research Institute's Contribution to Rice Varietal Yield Improvement in South-East Asia; ACIAR Impact Assessment Series Report No. 74; Australian Centre for International Agricultural Research: Canberra, Australia, 2001.

23. Yoshida, S.; Parao, F.T. Climate and Rice; International Rice Research Institute: Manila, Philippines, 1976.

24. Resurreccion, A.P.; Juliano, B.O. Properties of poorly digestible fraction of protein bodies of cooked milled rice. Plant Foods Hum. Nutr. 1981, 31, 119-128. [CrossRef]

25. Rose, T.J.; Rose, M.T.; Pariasca-Tanaka, J.; Heuer, S.; Wissuwa, M. The frustration with utilisation: Why have improvements in internal phosphorus utilisation efficiency in crops remained so elusive? Front. Plant Sci. 2011, 2, 1-5. [CrossRef] [PubMed]

26. Rose, T.J.; Erler, D.V.; Farzana, T.; Van Zwieten, L. Delayed permanent water rice production systems do not improve the recovery of ${ }^{15} \mathrm{~N}$-urea compared to continuously flooded systems. Eur. J Agron. 2016, 81, 46-51. [CrossRef]

27. Wissuwa, M.; Kondo, K.; Fukuda, T.; Mori, A.; Rose, M.T.; Pariasca-Tanaka, J.; Kretzschmar, T.; Haefele, S.M.; Rose, T.J. Unmasking novel loci for internal phosphorus utilization efficiency in rice germplasm through Genome-Wide Association Analysis. PLoS ONE 2015, 10, e0124215. [CrossRef] [PubMed]

(C) 2017 by the authors. Licensee MDPI, Basel, Switzerland. This article is an open access article distributed under the terms and conditions of the Creative Commons Attribution (CC BY) license (http:/ / creativecommons.org/licenses/by/4.0/). 